\title{
ROSYJSKA OPOZYCJA WOBEC ŚWIATA MODERNIZMU
}

\author{
RUSSIAN OPPOSITION AGAINST MODERNITY WORLD
}

\author{
MAREK JEDLIŃSKI
}

\begin{abstract}
Modernity is typically defined as a post-traditional historical period. Central to modernity is emancipation from religion and consequent secularization. In my article I analyze and interpret the ideological foundations of contemporary Russian neo-Euroasianism. This movement is led by Alexander Dugin, an important representative of Russian traditionalism and conservatism. What he postulates is to build an ideocratic orthodox-soviet state, which should include Ukraine.
\end{abstract}

Marek Jedliński, Uniwersytet im. Adama Mickiewicza w Poznaniu, Poznań - Polska, marekjedlinski@poczta.onet.pl

Na przestrzeni wieków między Rosją a Zachodem wielokrotnie dochodziło nie tylko do konfrontacji militarno-politycznej, ale również do konfrontacji w sferze myśli ( $w$ obszarze kultury). Narracja rywalizacji stawała się dominująca, a nierzadko bywała podstawą, niejako głównym założeniem wyjściowym, od przyjęcia którego podejmowano dyskurs z Zachodem. Europa niemal zawsze była punktem odniesienia dla myślicieli rosyjskich. Aleksander Dugin ${ }^{1}$ stwierdził nawet, że cała filozofia rosyjska powstała

\footnotetext{
${ }^{1}$ Aleksander Dugin jest liderem współczesnego neoeurazjatyzmu rosyjskiego, akademikiem, doradcą przewodniczącego Dumy Państwowej. W latach dziewięćdziesiątych Dugin traktowany był jako ekscentryczny intelektualista, o niewielkim znaczeniu; dziś jest znaczącym teoretykiem rosyjskiego tradycjonalizmu, częstym gościem programów publicystycznych i telewizyjnych. To postać ekscentryczna, charyzmatyczna, cynicznie bądź lekkomyślnie rzucająca agresywne hasła. Dugin jest autorem licznych prac naukowych - jednak wartość naukowa niektórych z nich może budzić uzasadnione wątpliwości poznawcze: szczególnie treść jego artykułów jest nachalnie tendencyjna, chaotyczna i pełna sprzeczności. W czasach młodości Dugin związał się z kręgiem rosyjskich pisarzy, poetów (i działaczy społecznych), połączonych fascynacją mistycyzmem, okultyzmem i ezoteryzmem oraz - spinającym klamrowo całość poglądów - tradycjonalizmem. Do tego kręgu zaliczyć należy między innymi: Eugeniusza Gołowina - poetę, filologa, okultystę (znawcę alchemii i mistycyzmu); Jurija Mamlejewa - prozaika, poetę, dramatopisarza; oraz Gejdara Dżemala - islamskiego działacza społeczno-politycznego. Na wczesne poglądy Dugina szczególny wpływ wywarł Eugeniusz Gołowin. Warto odnotować, że w latach dziewięćdziesiątych Dugin był ideologiem narodowych bolszewików Eduarda Limonowa. Na poglądy Dugina wpłynęła twórczość Fryderyka Nietsche-
} 
jako „reakcja” na filozofię europejską, włączając w to nurty umysłowe, które (w zamierzeniu) miały stanowić o wyjątkowości kultury rosyjskiej:

Nawet w sytuacji, kiedy myśliciele rosyjscy dążyli do oryginalności bądź byli w czymś oryginalni, oryginalność ta manifestowała się w formie kontrastu z filozofią Zachodu, porównania właśnie z nią [tłumaczenie moje - M. J.]².

Zachód był jednak zazwyczaj - co warto podkreślić - punktem odniesienia negatywnego. Świadczy o tym pobieżny przegląd stanowisk ideowych myślicieli rosyjskich różnych epok - rywalizacja z kulturą europejską była stałym motywem twórczości przedstawicieli najważniejszych nurtów ideowych Rosji: wspomnieć należy przykładowo o słowianofilstwie klasycznym, panslawizmie czy też euroazjatyzmie. Zresztą nawet $\mathrm{w}$ pisarstwie okcydentalistów rosyjskich znaleźć można schemat dyskursywny, opisujący przestrzeń Rosji i Europy w kategoriach binarnego rozróżniania dwóch światów: Zachodu i Rosji, nierzadko kategorialnie opisywanych jako dwie niewspółmierne, obce sobie przestrzenie (vide: Piotr Czaadajew) ${ }^{3}$.

Główną przesłanką niniejszych rozważań o rosyjskiej opozycji wobec świata modernizmu musiałoby być stwierdzenie, że ów modernizm był (jest) procesem (zjawiskiem) niepożądanym, szkodliwym, skoro myśliciele rosyjscy, a współcześnie tradycjonaliści w rodzaju Aleksandra Dugina, mieliby deprecjonować jego podstawy. W kontekście współczesnych wydarzeń politycznych warto ze szczególną uwagą przyjrzeć się rosyjskiej walce z kulturą zachodnią (modernizmem i postmodernizmem), czyli koncepcjom ideowym Dugina konstruowanym właśnie na silnej opozycji wobec Zachodu i płynących zeń przemian kulturowych. Powróćmy jednak do kwestii modernizmu - tj. właściwego przedmiotu niniejszego artykułu. Przyjąć można, wyraźnie problem symplifikując, iż nastąpiło w nim przekroczenie granic myślenia magiczno-mitycznego, czy też inaczej: wykroczenie poza wąską poznawczo postawę zaangażowania, myślenio-działania, działania sklejonego z myśleniem i zbudowanie postawy teoretycznej, pozwalającej na nabranie dystansu wobec obserwowanego świata. Postawę tę

go oraz - co istotne dla zrozumienia osnowy światopoglądowej lidera neoeurazjatyzmu - teoretyków i znawców tradycjonalizmu (integralnego) czy konserwatyzmu, takich jak: Mircea Eliade, Rene Guenon, Julius Evola. Szerzej: M. L a r u e 11 e, Aleksandr Dugin: A Russian Version of the European Radical Right?, Kennan Institute Occasional Papers, 2006, nr 294, s. 1-4, [w:] źródło elektroniczne: http://www.wilsoncenter.org/sites/default / files/OP294.pdf (05.09.2015).

2 А. Г. Д у г и н, Мартин Хайдеггер. Возможность русской философии, Академический Проект Гаудеамус, Москва 2011, s. 4.

3 Szerzej na ten temat: M. J e d 1 i ń s k i, Rosyjskie poszukiwania sensu i celu... Myśl historiozoficzna Iwana Kiriejewskiego, Aleksego Chomiakowa i Piotra Czaadajewa, Oficyna Wydawnicza Epigram, Bydgoszcz 2015. 
buduje przekonanie, że dopiero na podstawie przeprowadzonych obserwacji może dojść do uogólnień teoretycznych, opisujących faktyczność, stan świata; następnie wiedza ta może się przekształcić $\mathrm{w}$ wiedzę operacyjną, która nie ma już charakteru pierwszoosobowego, lecz jest akceptowana ponadindywidualnie. Choć - odnotujmy w tym miejscu - intersubiektywność przekonań nie stanowi jeszcze istoty modernizmu. Źródeł modernizmu, w który immanentnie wpisane jest wykroczenie poza ograniczenia świata magiczno-mitycznego, można by się doszukiwać już w starożytnej Grecji ${ }^{4}$. W Timajosie Platon wspominał, że każdy człowiek posługuje się mniemaniem, ale rozumowaniem tylko nieliczni ludzie i bogowie (51d).

Jeśli uznamy, że istotą modernizmu był (jest) rozwój nauk, to przypomnieć należy, że już Arystoteles opracował podwaliny metafizycznologiczne dla refleksji teoretycznej - uprawianej już nie w imię dobra, lecz prawdy bezinteresownej. Dla nauki nowożytnej doniosłe znaczenie będzie mieć wzmocnienie postawy obserwatora, co zawdzięczamy właśnie Stagirycie. W Metafizyce można również przeczytać, iż mądrość polega na poznaniu przyczyn pierwszych i zasad ${ }^{5}$, doświadczenie zaś nie może zastąpić teorii. Zdaniem Sergiusza Awierincewa właśnie na koncepcjach Arystotelesa ufundowane zostały podstawy zachodniego racjonalizmu: poprzez stworzenie logiki rozumianej jako "organ” myśli6. Arystotelizm wyznaczył główny nurt tradycji myślowej na Zachodzie, pozwalając szybciej przekroczyć ograniczenia myślenia magiczno-mitycznego. Awierincew wyraża przekonanie, że arystotelizm oddziaływał pośrednio nawet na zwykłych (nieuczonych) ludzi, a scholastyka, logika czy też sylogizmy zbudowały wewnętrzną formę cywilizacji zachodniej ${ }^{7}$. Zauważmy też w procesie na-

4 To Grecy wzbogacili kulturę europejską o element, którego wcześniej w takim kształcie nie posiadała: mowa tu o refleksji teoretycznej i przekroczeniu postawy zaangażowania. To z kolei przyczyniło się do rozwoju nauki w świecie Zachodu: kategorie logiki stworzyły nowy sposób myślenia. To Grecy i ich myślenie pojęciowe ukonstytuowało - mówiąc językiem Anny Pałubickiej - gramatykę kultury europejskiej i określiło oblicze naukowe przyszłego świata euroatlantyckiego. Problem ten został szczegółowo omówiony w pracy Anny Pałubickiej Gramatyka kultury europejskiej (A. P a ł u b i c k a, Gramatyka kultury europejskiej, Epigram, Bydgoszcz 2013).

${ }^{5}$ Zob. A r y s t o t e l e s, Metafizyka, t. I, tłum. T. Żeleźnik, oprac. M. A. Krąpiec, A. Maryniarczyk, Redakcja Wydawnictw Katolickiego Uniwersytetu Lubelskiego, Lublin 1996, s. 10, 107.

${ }^{6}$ Zob. S. A w i e r i n c e w, Arystotelizm chrześcijański w tradycji zachodniej i problemy wspótczesnej Rosji, tłum. R. Mazurkiewicz, „Znak” 1992, nr 6, s. 71; zob. wykład na temat zachodniego racjonalizmu autorstwa Awierincewa: С. С. А в е р и н ц е в, Два рождения европейского рационализма, „Вопросы философии” 1989, № 3, s. 3-13.

7 Człowiek Zachodu - wyjaśnia następnie Awierincew - może nigdy nie czytać Arystotelesa; może nigdy nie usłyszeć jego imienia; może nawet uważać się za zdecydowanego 
rodzin modernizmu znaczenie św. Tomasza z Akwinu. Wedle Akwinaty Bóg jest co prawda stwórcą wszystkiego i pierwszą przyczyną - causa prima, ale rzeczy stworzone mogą jednak wywoływać skutki same z siebie, które człowiek może poznawać. Aktywność rozumu - według św. Tomasza - nastawiona była na poznanie prawdy. Warto podkreślić, że Akwinata rozpoznawał korelację między myślą a rzeczami ${ }^{8}$. W modernizmie ukonstytuowały się właśnie kryteria obiektywnego istnienia, najwyraźniej dostrzegalne $\mathrm{w}$ teoriach naukowych. Teoria staje się wiarygodna, jeśli jest poddana, z pozytywnym rezultatem, kontroli intersubiektywnej, opartej na treści doświadczenia percepcyjnego (zmysłowego). Od czasów nowożytnych to nie autorytet podmiotu, mniemania, przesądy są źródłem wiedzy prawomocnej (dodajmy: głównie w sferze nauki). Prawdziwość przekonania uzasadnia się poprzez kontrolę empiryczną, przy zachowaniu dystansu epistemologicznego (i kontroli intersubiektywnej).

W Rosji okoliczności historyczne ukierunkowały przemiany kulturowe i ukształtowały tradycję myślową odmiennie niż na Zachodzie.

Historia kultury rosyjskiej potoczyła się w taki sposób, że od chrztu Rusi aż po nasze czasy chrześcijańska recepcja Arystotelesa nie dokonała się tu nawet w skali bizantyjskiej ${ }^{9}$

- wyjaśnia Awierincew. Rosyjski renesans religijny przełomu XIX i XX w. miał wyraźne ukierunkowanie antypozytywistyczne i antymaterialistyczne, bliższy był mu duch platonizmu niż arystotelizmu. Znów nie doszło wobec tego do spotkania ze Stagirytą; co więcej: „Arystoteles nie został przeczytany przez wykształcony ogół społeczeństwa Rosji do dnia dzisiejszego"10 - konkluduje Awierincew.

W podobnym duchu pisał Gustaw Szpet, myśliciel-entuzjasta fenomenologii, autor Szkicu rozwoju filozofii rosyjskiej (1922). Szpet wskazywał na następujące okoliczności historyczno-polityczne i uwarunkowania kulturowe:

Rosja weszła do rodziny europejskiej. Ale jako sierota. [...] stała się chrześcijańska, ale bez tradycji antycznej i bez historycznego dziedzictwa kulturowego. Góry Bałkanów nie były skore wypuścić źródeł kultury antycznej na równiny rosyjskie [tłumaczenie moje - M. J.] ${ }^{11}$.

przeciwnika wszystkiego, co się z tym imieniem łączy. Mimo to będzie on w pewnym sensie "arystotelikiem”, gdyż wpływ arystotelesowskiej scholastyki na formowanie się kultury zachodniej był tak przemożny, ze odcisnął swe piętno nawet na używanych nieświadomie zwrotach leksykalnych.

Tamże, s. 78 .

8 Por. G. V e r b e k e, Prawda i nieprawda w ludzkim poznaniu wedtug św. Tomasza, „Roczniki Filozoficzne” 1975, t. XXIII (z. 1), s. 70-71.

${ }^{9} \mathrm{~S}$. A w i e ri n c e w, Arystotelizm chrześcijański..., op. cit., s. 77.

10 Ibidem.

${ }^{11}$ Г. Ш п е т, Очерк развития русской философии, т. I, РОССПЭН, Москва 2008, s. 54. 
Dla człowieka Zachodu, dzięki znajomości łaciny, antyk był otwartą księgą, z której czerpał inspirację i której wiedzę wykorzystywał do pokonywania kryzysów wartości; tymczasem - surowo i nie bez ironii wyjaśnia czytelnikowi rosyjski badacz kultury -

ochrzcili nas po grecku, ale język dali nam bułgarski. Cóż mógł wnieść język narodu pozbawionego tradycji kulturowej, literatury i historii? Bizancjum nie wytrzymało naporu dzikiego Wschodu i prędko schroniło swe dziedzictwo-skarby na Zachodzie [tłumaczenie moje - M. J.] ${ }^{12}$.

Jednym słowem: Rosja pozbawiona była dziedzictwa antyku. Rosja była chrześcijańska, miała nawet - jak pisał klasyk słowianofilstwa Iwan Kiriejewski - barbarzyńców, lecz żywiołem, którego zabrakło w jej rozwoju historycznym, był klasyczny świat starożytny13.

Jeśli źródła modernizmu europejskiego będziemy się doszukiwać w dziedzictwie greckim, to naszą uwagę zwrócić musi negatywne, rosyjskie odniesienie do tradycji greckiej - i konsekwencje z niego wynikające. Otóż warto zwrócić uwagę na moment odcięcia się od dziedzictwa Bizancjum. Przyjąć można, że nastąpiło ono około XV-XVI w. Przebieg wydarzeń historycznych uczynił z Moskwy siłę unifikacyjną, zdolną jednoczyć (i powiększać) ziemie ruskie oraz bronić ortodoksji. Bizancjum upadło i tym samym chrześcijaństwo wschodnie straciło wsparcie polityczno-militarne. Ćwierć wieku po tym wydarzeniu Rusini zrzucili jarzmo tatarskie, co odczytywane było przez nich jako przejaw woli Opatrzności. Powstała w XVI wieku idea Moskwy-Trzeciego Rzymu była nie tylko następstwem konfrontacji z Zachodem, ale również efektem negatywnego nastawienia do tradycji greckiej. Wierzono, że Drugi Rzym (Konstantynopol) upadł krótko po przyłączeniu się do heretyków (unia florencka). Jako że Pierwszy Rzym (katolicki) skazany był na upadek, gdyż sprzeniewierzył się czystemu doktrynalnie chrześcijaństwu, Drugi zaś Rzym wsparł herezję, Opatrzność powierzyła więc Rusinom zadanie ochrony chrześcijaństwa. Moskwa miała być Trzecim i ostatnim Rzymem. Myśl tę wyraził mnich Filoteusz w traktatach epistolarnych (lata 30-40. XVI w.), nadając ostateczny kształt koncepcji Moskwy jako Trzeciego Rzymu: „,esarstwo greckie zostało zburzone i nie odbuduje się: wszystko to zdarzyło się, gdyż zaprzedali prawosławną wiarę grecką katolikom"14 [tłumaczenie moje - M. J.]. Moskwa (w intencji

12 Ibidem, s. 55.

13 Por. И. В. К и р е е в с к и й, Девятнадизатый век, [w:] tegoż, Полное собрание сочинений $b$ двух томах, т. I, ред. М. Гершензон, Типография Императорского Московского Университета, Москва 1911, s. 97-99.

14 Послание о неблагоприятных днях и часах, [w:] Памятники литературы Древней Руси. Конеи XV - первая половина XVI века, ред. Л. А. Дмитриев, Д. С. Лихачев, Художественная литература, Москва 1984, s. 449; Por. Д. С т р е м о у х о в, Москва - Тре- 
twórców owej idei) miała być strażniczką tradycji i opoką świata sprzed przemian, jakie dokonać się miały w epoce modernizmu. Ruś Moskiewska (potem Rosja) miała się stać, zgodnie z wolą książąt moskiewskich, carów i duchowieństwa, centrum świata prawosławnego, a że prawosławie postrzegano jako prawdziwe chrześcijaństwo, to tym samym miała się stać centrum świata chrześcijańskiego ${ }^{15}$.

Kolejne wieki przyniosły dalsze wzmacnianie tożsamości kulturowej (narodowej, cywilizacyjnej) w oparciu o konfrontację ideową ze światem Zachodu. Dodajmy w tym miejscu: ze światem podlegającym coraz silniejszym tendencjom sekularyzacyjnym (co stanowi jedną z cech konstytuujących istotę modernizmu). Kategorialne rozróżnianie światów (rosyjskiego i zachodniego, sacrum i profanum) nacechowane było, w twórczości większości reprezentantów myśli rosyjskiej, silną antynomią; na tyle silną, iż przeżywanie "rosyjskości” oznaczać musiało odczuwanie przez człowieka uzależnienia od rzeczywistości sakralnej i wyobcowanie z tego wszystkiego, co nie było $\mathrm{z}$ nią zgodne. $\mathrm{W}$ konsekwencji rodziło to wręcz wrogie nastawienie wobec tego, co obce, co nie-święte ${ }^{16}$. Tę polaryzację światów rozpoznać można, po raz pierwszy wyartykułowaną w sposób usystematyzowany, w pisarstwie słowianofilów klasycznych: przede wszystkim Iwana Kiriejewskiego i Aleksego Chomiakowa ${ }^{17}$. Zresztą, jak zauważył George Kline, większość myślicieli rosyjskich była ukierunkowana tradycjonalistycznie, czyli antymodernistycznie ${ }^{18}$. Dzisiejszy antymodernistyczny tradycjonalizm rosyjski zaczął się kształtować w latach 60-70. w kręgu pisarzy, poetów, działaczy społecznych i myślicieli - dysydentów czasów radzieckich - takich jak Jewgienij Gołowin, Jurij Mamlejew, Gejdar Dżemal i w końcu Aleksander Dugin. Dugin w książce Archeomodernizm wyjaśnia, że Rosjanie są głęboko tradycjonalistyczni i antymodernistyczni - postępowcy i okcy-

тий Рим: источник доктрины, [w:] Из истории русской культуры. Киевская и Московская Русь, т. II, Языки славянской культуры, Москва 2002, s. 429; Л. И. Н о в и к о в а, И.Н. С из е м с к а я, Идеи мессианизма в русской философии истории, „Общественные науки и современность” 1995, № 6, s. 70-71; B. U s p i e n s k i, Religia i semiotyka, wybrał, przełożył i przedmową opatrzył B. Żyłko, Słowo / Obraz Terytoria, Gdańsk 2001, s. 50.

15 Por. A. H a u k e - L i g o w s k i OP, Od "Świętej Rusi” do Imperium Rosyjskiego, "Znak" 1982, nr 6 (331), s. 483-487.

16 Por. M. B r o d a, "Zrozumieć Rosje”? O rosyjskiej zagadce-tajemnicy, Wydawnictwo Naukowe „Ibidem”, Łódź 2011, s. 69-71.

17 Najobszerniejsze studium na temat ruchu słowianofilskiego stanowi fundamentalna praca autorstwa Andrzeja Walickiego: A. W a 1 i c k i, W kregu konserwatywnej utopii. Struktura i przemiany rosyjskiego stowianofilstwa, Wydawnictwo Naukowe PWN, Warszawa 2002.

18 Por. G. L. K 1 i n e, Rosyjscy i zachodnioeuropejscy myśliciele o tradycji, nowoczesności i przyszłości, [w:] Europa i co z tego wynika, „Res Publica”, Warszawa 1990, s. 159, 165. 
dentaliści w dzisiejszej Rosji stanowią zaledwie mało znaczący margines społeczeństwa ${ }^{19}$. Przyjrzyjmy się zatem współczesnej rosyjskiej odpowiedzi na przemiany zachodzące $w$ kulturze europejskiej. Najodpowiedniejszym źródłem dającym możliwość choć częściowego zrekonstruowania (i zrozumienia) rosyjskiego spojrzenia na świat modernizmu (i postmodernizmu) mogłyby być wypowiedzi głównego przedstawiciela współczesnego tradycjonalizmu rosyjskiego - Aleksandra Dugina. Jednak wnikliwa analiza setek stron książek Dugina prowadzi do konkluzji, że jego tradycjonalizm jest kontynuacją narracji tradycjonalistów francuskich (takich jak Bonald, Ballanche czy też de Lamennais), ukierunkowanych antymodernistycznie. Nie można zatem zrozumieć duginizmu bez dokonania zwięzłej charakterystyki założeń ideowych tradycjonalizmu powstałego jako odpowiedź na rewolucję francuską. Rewolucja - jak wyjaśniali tradycjonaliści - nie była wydarzeniem przypadkowym; była następstwem nader złożonego procesu o zasięgu powszechnym, nieuchronnym następstwem rozwoju kultury nowożytnej. Korzeniem rewolucji i początkiem rozkładu starego świata była reformacja i protestantyzm, jego istotą - jak każdej schizmy i herezji - jest protest, bunt przeciwko władzy, autorytetowi Kościoła, przeciwko władzy uświęconej przez tradycję, przeszłość i jej sacrum (a tym samym przeciwko samemu Bogu). Była to rebelia indywiduów, które wzgardziwszy tradycją oraz autorytetem kościoła powszechnego, uwierzyły w siłę swego rozumu i zapragnęły wedle własnego uznania interpretować słowo objawione. Tradycje i władzę zastąpiła anarchia dogmatów. Konsekwencją schizmy religijnej był głęboki kryzys polityczny: protestancki sceptycyzm, rozbuchany indywidualizm wyzwolił lud spod mocy oddziaływania tradycji, autorytetu i władzy - pełen pychy, wyemancypowany lud zwrócił się przeciwko władzy świeckiej. Anarchia dogmatów musiała się zakończyć anarchią społeczną, a więc rewolucją. Anarchia protestancka opanowała również filozofię europejską: tradycjonaliści francuscy wskazywali na Kartezjańską afirmację rozumu indywidualnego: wedle Kartezjusza jednostka nie musi się odwoływać do tradycji i nie musi się poddawać autorytetom, lecz w sobie samej odnajduje źródło wiedzy prawomocnej i pewności. Wiek XVIII przyniósł już ateizm, atrofię uczuć, anihilację ideałów, a filozofia materialistyczna $\mathrm{w}$ swym programie sensualistycznym podporządkowała duszę ciału, aż w końcu ją uśmierciła, ujmując człowieka na podobieństwo maszyny czy też zwierzęcia.

Dugin w książce o wymownym tytule Postfilozofia wyraża opinię, patrząc z perspektywy historiozofii tradycjonalistycznej, że obecna epoka świecka (i filozofia świecka - jak pisze) to tylko krótki interwał na linii czasu historycznego zdominowanego przez myślenie tradycjonalistyczne

19 Zob. А. Г. Д у г и н, Археомодерн, Арктогея, Москва 2011, s. 76-77. 
i religijne ${ }^{20}$; przez świat zaczarowany, wypełniony przez przestrzeń sakralną, porządkowany przez wiarę $\mathrm{w}$ cuda, a nie, wypracowane $\mathrm{w}$ dobie modernizmu europejskiego, kryteria realnego (obiektywnego) istnienia ${ }^{21} . \mathrm{W}$ tym kontekście Dugin stwierdza, że Rosjanom obce jest pojęcie realnego istnienia, a niedorozwój filozofii rosyjskiej dowodzi, że Rosjanie pozostawali znacznie dłużej aniżeli Europejczycy na etapie społeczeństwa tradycyjnego ${ }^{22}$. Co więcej, Dugin oznajmia prowokacyjnie, że Rosjanie nadal są społeczeństwem trwającym w stanie premodernizmu: „My, Rosjanie jesteśmy bardzo archaicznym narodem... Modernizm, który z takim trudem do naszych głów wbijali [...] jakoś szybko roztrwoniliśmy" [tłumaczenie moje: M. J.]23. Być może przyczyna tego leży $\mathrm{w}$ tym, że tradycja prawosławna - jak przekonuje Dugin - bliższa jest nie kreacjonizmowi chrześcijańskiemu, lecz wierzeniom wspólnot wczesnotradycyjnych ${ }^{24}$. Z kolei w okresie radzieckim - jak wyjaśnia Dugin w książce Archeomodernizm - nastąpiła nie modernizacja, lecz jeszcze silniejsze zaczarowanie świata ${ }^{25}$. Komunizm w wersji (wydaniu) radzieckiej był nacjonalistyczny (wbrew internacjonalnym deklaracjom), tradycjonalistyczny, patriarchalny i wrogi wobec różnorakich mniejszości. Świat radziecki był monolityczny, antypluralistyczny, a właściwością modernizmu jest przecież emancypacja umysłu, opuszczenie świata mitu i tym samym, mówiąc językiem Kantowskim, wyjście ludzkości z okresu dziecięctwa. Treść przywołanej pracy porządkuje wielokrotnie eksplikowana myśl, iż Rosjanie zatrzymali się w stadium mentalności zbiorowej i nie doszli do epoki modernizmu. Tym samym - argumentuje autor - Rosjanie rozumują na sposób familiarny, opisują otoczenie w kategoriach więzi krwi - dlatego państwo i naród jest rodziną, której woli należy się podporządkować. Jest to schemat typowy dla świata premodernizmu.

W wizji Duginowskiej nie tylko Rosjanie znajdują się w strukturach myślenia archaicznego: większość świata niezachodniego tkwi w epoce premodernizmu lub cofa się do niego ${ }^{26}$. W Rosji wyłącznie elity, i to w niewielkim stopniu, przyjęły modernistyczny sposób myślenia, lud natomiast trwa w epoce premodernizmu. Dugin uważa, że elity europeizowały się z obawy przed agresją i kolonizacją. Dlatego - jak wyjaśnia - było to tylko obronne, taktyczne i powierzchowne przyjęcie niektórych elementów, wrogiego duszy rosyjskiej modernizmu ${ }^{27}$. Tymczasem dla duszy rosyjskiej

${ }^{20}$ Por. А. Г. Д у г и н, Постфилософия. Три парадигмы $b$ истории мысли, Евразийское Движение, Москва 2009, s. 71.

21 Por. ibidem, s. 237, 395-396.

22 Por. ibidem, s. 108, 238.

23 Ibidem, s. 167.

24 Por. ibidem, s. 125-126.

25 Por. А. Г. Д у г и н, Археомодерн, op. cit., s. 22, 33.

26 Por. ibidem, s. 25.

27 Zob. ibidem, s. 67. 
właściwy jest chaos: „Byt rosyjski przebywa w chaosie, w krainie rosyjskiej, na niwie i w polu" [tłumaczenie moje: M. J.] ${ }^{28}$. Dugin wyraża przekonanie, że w Rosji zabrakło filozofii w kształcie podobnym do zachodniego (europejskiego) i wschodniego (np. chińskiego), ponieważ rosyjski Dasein jest rezultatem aktywności wielkiego żywiołu: antyracjonalnego chaosu ${ }^{29}$. Z kolei współczesna filozofia zachodnia, czy też - jak woli pisać Dugin - postfilozofia, ukazuje złożoność położenia, w jakim znajduje się kultura europejska: to negacja paradygmatu modernizmu, przy jednoczesnym zamknięciu drogi powrotnej do premodernizmu ${ }^{30}$. Obecnie powrót do świata uorganizowanego przez tradycję jest prawie niemożliwy, gdyż antropologia modernizmu stała się częścią świadomości Europejczyka, a Kartezjanizm jest obecny w kulturze masowej, w życiu społecznym - to rozumienie człowieka jako indywiduum wyłącznie ${ }^{31}$. Nastąpiła epoka postczłowieka - oznajmia Dugin. Nihilistyczny program humanizmu zakończył się na ukształtowaniu jednostki autonomicznej: stała się ona nie tylko miarą wszystkich rzeczy; ostatnim etapem jej ewolucji jest zanegowanie samej siebie ${ }^{32}$. Postmodernizm - w perspektywie lidera neoeurazjatyzmu - jest mimo wszystko logiczną konsekwencją rozwoju tych elementów, które składały się na modernizm. Autor ma tu na myśli przede wszystkim konsekwentną wiarę w nieomylność rozumu ludzkiego i indywidualizm. Notabene, jak stwierdza Dugin, w przypadku kultury rosyjskiej bezprzedmiotowa jest dyskusja o roli postmodernizmu w rozwoju myśli rosyjskiej, gdyż myśl ta w ogóle nie doszła do etapu modernizmu ${ }^{33}$. Neoeuroazjata uważa, że główny zarzut postmodernistów wobec modernistów polega na tym, że modernizm okazał się niekonsekwentnie modernistyczny, to znaczy: postmodernizm nie odrzuca dorobku oświecenia, lecz tylko te jego elementy, które okazały się niedostatecznie postępowe, oświecone, te, które niedostatecznie zerwały $\mathrm{z}$ tradycją. Tymczasem - jak przekonuje Dugin - obecnie w świecie Zachodu nie ukonstytuowano nowych kryteriów realnego, obiektywnego istnienia, a nauka staje się obszarem nowego nawarstwiania się mitów, naiwnych aksjomatów, irracjonalnych dogmatów. Przy tym postmoderniści naiwnie sądzą, że, w odróżnieniu od modernistów, mogą się wyzwolić od dogmatów ${ }^{34}$.

A więc diagnoza Duginowska, zgodnie z retoryką tradycjonalistyczną, akcentuje głęboki kryzys współczesności. Lekarstwem na ów kryzys ma być (od lat postulowane przez Dugina) zaprowadzenie porządku teokra-

\footnotetext{
28 А. Г. Дугин, Мартин Хайдеггер..., ор. cit., s. 293.

29 Zob. ibidem.

30 Por. А. Г. Д у г и н, Постфилософия..., op. cit., s. 68.

31 Por. ibidem, s. 129.

32 Por. ibidem, s. 157.

33 Zob. А. Г. Д у г и н, Археомодерн, op. cit., s. 116-117.

34 Por. А. Г. Д у г и н, Постфилософия..., ор. cit., s. 462-464.
} 
tycznego, czyli - jak deklaruje - religijne uorganizowanie kultury, moralności i polityki. „Prawosławie - naszą jedyną drogą" - oznajmia lider neoeurazjatyzmu ${ }^{35}$. Duginowskie hasła zbudowania ideokratycznego, wspólnotowego, prawosławnego i sowiecko-faszystowskiego zarazem państwa prawdy jawią się niczym egzotyczne fantazmaty, ale konfrontacja owego produktu wybujałej wyobraźni ekscentrycznego intelektualisty z rzeczywistością społeczno-polityczną współczesnej Rosji zmusza do uważnego wczytania się w jego koncepcje. Dugin od lat dziewięćdziesiątych wieści zaprowadzenie porządków konserwatywnej, premodernistycznej rewolucji (w obszarze polityki wewnętrznej) i pozbieranie rozrzuconych części dawnego imperium (w obszarze polityki zewnętrznej). Postulaty te mają obecnie istotne znaczenie, co ujawnia się szczególnie w kontekście konfliktu rosyjsko-ukraińskiego. Ukraina stanowiła strategiczny obszar dawnego imperium. Odzyskanie nad nią kontroli jest conditio sine qua non powodzenia dalszej rosyjskiej ekspansji kulturowo-polityczno-militarnej. Kijów jest dla Dugina kolebką państwowości ruskiej, Wielkim Początkiem przyszłego imperium rosyjskiego. Lider neoeurazjatyzmu twierdzi, że Rosja dla dobra Ukrainy chce ją odciągnąć od zgnitego moralnie Zachodu, świata postmodernistycznego, jako nieuchronnej konsekwencji modernizmu. Dugin wielokrotnie pisze o toczącej się na świecie wielkiej wojnie kulturowo-cywilizacyjnej: między liberalno-indywidualistycznym i laickim, modernistyczno i postmodernistycznym Zachodem a religijno (tradycjonalistyczno)-wspólnotowym i premodernistycznym Wschodem. Lider neoeurazjatyzmu wpisuje cele geopolityczne $\mathrm{w}$ szerszą perspektywę cywilizacyjną: mowa tu o kierowanej przez Rosję misji odrodzenia Europy, czyli cofnięcia jej do stanu premodernizmu. Dlatego artykuł Czarny maj zakończył Dugin wezwaniem do jak najszybszego opanowania Ukrainy i rozpoczęcia triumfalnego marszu na Zachód, plastycznie przedstawiając obraz zepsutych płodów cywilizacji zachodniej, rozgniatanych przez gąsienice rosyjskich czołgów prawosławnej i konserwatywnej rewolucji ${ }^{36}$.

W świecie konstruowanym przez Dugina rozpoznajemy wobec tego dodatkowo postawę misyjności, wynikającą z poczytywania siebie za depozytariusza prawdy. W tym miejscu pojawia się pragnienie przeobrażenia idei w czyn. Mianowicie depozytariusz prawdy, chcąc wiedzę o niej upowszechnić, zwykle nad cel przedkłada środki, co może prowadzić do nadania sensu, nierzadko nadrzędnego, agresji. Ekspansja militarno-polityczna może być jednym z narzędzi upowszechnienia właśnie owej prawdy 2015).

35 Zob. źródło elektroniczne: http://www.sorokinfond.ru/index.php?id=1164 (18.09.

36 Zob. źródło elektroniczne: http://ruskline.ru/opp/2014/05/7/chernyj_maj_ili_ tanki_na_zapad/ (20.09.2015). 
(z punktu widzenia agresora) tudzież jedynej idei, jeszcze inaczej ujmując: zbioru przekonań normatywnych, zdolnych obejmować świat ludzki całościowo, porządkować go, organizować, wyjaśniać niepojęte i szczegółowo określać system nakazów i zakazów, jakich człowiek, by osiągnąć stan szczęścia, winien przestrzegać. $W$ tym przypadku stan ten identyfikowany jest $\mathrm{z}$ powrotem do świata sprzed przemian modernizmu i postmodernizmu. W duginowskim, tradycjonalistycznym, premodernistycznym sposobie myślenia, zorientowanym totalnie i maksymalistycznie, świat opisywany jest jako „święty" albo jako "grzeszny", "dobry" albo "zły", coś jest „boskie" bądź "szatańskie”, "akcydentalne” bądź „wieczne”, a przeciwnik odbierany jest jako nosiciel zła, które należy unicestwić.

\section{Bibliografia}

A r y s t o t e l e s, Metafizyka, t. I, tłum. T. Żeleźnik, oprac. M. A. Krąpiec, A. Maryniarczyk, Redakcja Wydawnictw Katolickiego Uniwersytetu Lubelskiego, Lublin 1996.

A w i e r i n c e w S., Arystotelizm chrześcijański w tradycji zachodniej i problemy wspótczesnej Rosji, tłum. R. Mazurkiewicz, "Znak” 1992, nr 6.

B r o d a M., "Zrozumieć Rosję"? O rosyjskiej zagadce-tajemnicy, Wydawnictwo Naukowe „Ibidem”, Łódź 2011.

H a u k e - L i g o w s k i A., Od "Świętej Rusi” do Imperium Rosyjskiego, "Znak” 1982, nr 6 (331).

J e d 1 i ń s k i M., Rosyjskie poszukiwania sensu i celu... Myśl historiozoficzna Iwana Kiriejewskiego, Aleksego Chomiakowa i Piotra Czaadajewa, Oficyna Wydawnicza Epigram, Bydgoszcz 2015.

K 1 i n e G. L., Rosyjscy i zachodnioeuropejscy myśliciele o tradycji, nowoczesności i przyszłości, [w:] Europa i co z tego wynika, "Res Publica”, Warszawa 1990.

L a r u e 11 e M., Aleksandr Dugin: A Russian Version of the European Radical Right? Kennan Institute Occasional Papers, 2006, no. 294, s. 1-4, [w:] źrodło elektroniczne: http://www.wilsoncenter.org/sites/default/files/OP294.pdf (05.09.2015).

P a $\nmid$ u b i c k a A., Gramatyka kultury europejskiej, Oficyna Wydawnicza Epigram, Bydgoszcz 2013.

U s p i e n s k i B., Religia i semiotyka, wybrał, przełożył i przedmową opatrzył B. Żyłko, Słowo / Obraz Terytoria, Gdańsk 2001.

V e r b e k e G., Prawda i nieprawda w ludzkim poznaniu wedtug św. Tomasza, „Roczniki Filozoficzne" 1975, t. XXIII (z. 1).

W a 1 i c k i A., W kregu konserwatywnej utopii. Struktura i przemiany rosyjskiego stowianofilstwa, Wydawnictwo Naukowe PWN, Warszawa 2002.

Źródło elektroniczne: http://ruskline.ru/opp/2014/05/7/chernyj_maj_ili_tanki_na_zapad/ (20.09.2015).

Źródło elektroniczne: http://www.sorokinfond.ru/index.php?id=1164 (18.09.2015). 
А в е р и н ц е в С. С., Два рождения европейского рационализма, „Вопросы философии" 1989, № 3.

Д у г и н А. Г., Археомодерн, Арктогея, Москва 2011.

Д у г и н А. Г., Мартин Хайдеггер. Возможность русской философии, Академический Проект Гаудеамус, Москва 2011.

Д уг и н А. Г., Постфилософия. Три парадигмы в истории мысли, Евразийское Движение, Москва 2009.

К и р е е в с к и й И. В., Девятнадцатый век, [w:] tegoż, Полное собрание сочинений b дbyx mомах, т. I, ред. М. Гершензон, Типография Императорского Московского Университета, Москва 1911.

Н о в и к о в а Л. И., С и з е м с к а я И. Н., Идеи мессианизма в русской философии истории, „Общественные науки и современность” 1995, № 6.

Послание о неблагоприятных днях и часах, [w:] Памятники литературы Древней Руси. Конеи XV - первая половина XVI века, ред. Л. А. Дмитриев, Д. С. Лихачев, Художественная литература, Москва 1984.

С т р е м о у х о в Д., Москва - Третий Рим: источник доктрины, [w:] Из истории русской культуры. Киевская и Московская Русь, т. ІІ: Языки славянской культуры, Москва 2002.

Ш п е т Г., Очерк развития русской философии, т. І, РОССПЭН, Москва 2008. 